\title{
Perspektif Hukum Feminis terhadap Aturan Fleksibilitas Pasar Tenaga Kerja di Indonesia
}

\author{
Agus Pratiwi* \\ DOI: https://doi.org/10.22304/pjih.v4n1.a3
}

\begin{abstract}
Abstrak
Studi ini menggambarkan bagaimana fleksibilitas pasar tenaga kerja yang menjadi nafas dalam hukum perburuhan Indonesia memiliki dampak kebijakan terhadap konstruksi gender. Sebaliknya konstruksi gender juga menentukan bagaimana fleksibilitas pasar tenaga kerja dipraktikkan oleh pemerintah. Desk study terhadap teks-teks lama tentang feminis, hukum feminis, dan perburuhan penting untuk memahami kesinambungan antara fenomena perburuhan di masa lalu dan fenomena perburuhan yang menjadi trend saat ini. Dengan perspektif feminis, arus utama analisis perburuhan yang meyakini bahwa kebijakan fleksibilitas baru terjadi di era Undang-Undang Nomor 13 Tahun 2003 tentang Ketenagakerjaan menjadi tidak relevan. Perspektif feminis melihat bahwa fleksibilitas bagi perempuan sudah terjadi sejak gelombang feminisasi manufaktur di era Hubungan Industrial Pancasila di masa Orde Baru, yang mana berpengaruh pada skema-skema fleksibilitas saat ini. Temuan-temuan melalui desk study ini diverifikasi melalui organic feminist inquiry, yang mana para kolaborator studi ini turut menganalisis temuan-temuan tersebut. Pada akhirnya, studi ini sangat relevan untuk meninjau ulang kebijakan-kebijakan perburuhan maupun kebijakan-kebijakan pemberdayaan perempuan yang justru kontraproduktif dengan upaya pengarusutamaan gender.
\end{abstract}

Kata kunci: fleksibilitas, gender, ketenagakerjaan, perempuan, feminis

\section{Feminist Legal Perspectives on the Regulation of Labor Market Flexibility in Indonesia}

\begin{abstract}
This study describes how labor market flexibility constituting the main spirit in the Indonesian labor law has had a strong regulatory impact on the gender construction. Oppositely, the gender construction has also determined the schemes of labor market flexibility enacted by the Indonesian government. The desk study to the classic texts of feminist, feminist law, and labor is important to reveal the sustainability of the labor phenomenon in the previous regimes within the current labor trend and the women empowerment trend. Through the feminist perspectives, the mainstream of most labor analyses, which defend that the flexibility policy has been enabled by enacting Act Number 13 Year 2003 concerning Manpower becomes irrelevant. The feminist perspectives find that, for women, flexibility has been developed since the feminization wave in manufacture sectors within the era of the Pancasila Industrial Relations during the New Order regime,

PADJADJARAN Jurnal IImu Hukum Volume 4 Nomor 1 Tahun 2017 [ISSN 2460-1543] [e-ISSN 2442-9325]

* Dosen Fakultas Hukum Universitas Padjadjaran, Jl. Dipati Ukur No. 35 Bandung, a.pratiwi@unpad.ac.id, S.H. (Universitas Indonesia), LL.M. (Universiteit van Tilburg).
\end{abstract}


which has influenced the current flexibility schemes. This finding through the desk study has been verified through an organic feminist inquiry, in which the research collaborators have taken part in analyzing the finding. Finally, this study is relevant to review the labor regulations as well as women's empowerment policies, which are, in fact, counterproductive to the gender mainstreaming strategy.

Keywords: flexibility, gender, labour, women, feminist.

\section{A. Pendahuluan}

Fleksibilitas merupakan sebuah upaya untuk beradaptasi dengan cepat terhadap perubahan-perubahan pasar yang tidak menentu dengan cara mengantisipasi ketidaksempurnaan dan inefisiensi kinerja institusi pasar. ${ }^{1}$ Fleksibilitas merupakan strategi yang diprakarsai oleh Organization for Economic Cooperation and Development (OECD), sebuah organisasi internasional negara-negara industri, sejak tahun 1970. Salah satu penerapan fleksibilitas adalah penciptaan fleksibilitas pasar tenaga kerja. Indonesia merupakan anggota ke-34 Development Centre OECD. OECD mempromosikan fleksibilitas pasar tenaga kerja sebagai jalan keluar dari masalah pengangguran sejak pencanangan fleksibilitas untuk pertama kalinya. ${ }^{2}$

Masalah pengangguran yang menjadi alasan penerapan fleksibilitas merupakan dampak dari kegagalan kompetitor negara-negara kapitalis, yakni negara-negara kesejahteraan kapitalis dan negara-negara sosialis, dalam mempertahankan era statutory regulation. ${ }^{3}$ Pada era tersebut, pasar tenaga kerja diatur dengan berbagai jaminan, seperti jaminan hubungan kerja, jaminan pendapatan, dan jaminan kebebasan berserikat. Hampir seluruh skema pekerjaan adalah penuh waktu. Namun di negara-negara sosialis, terlalu ketatnya kontrol negara berujung pada stagnansi produktivitas karena sistemnya yang menutup berbagai kesempatan untuk mengembangkan sistem produksi melalui hubungan kerja. Sementara di negara-negara kesejahteraan kapitalis, negara terbukti tidak mampu menyediakan pembaruan pasar tenaga kerja dan jaminan pendapatan dalam masa ekonomi terbuka, sebagai dampak dari globalisasi. ${ }^{4}$ Pada era ini, pasar tenaga kerja secara berangsur diatur dengan fleksibel dari sisi waktu, lokasi, dan keterampilan.

1 Guy Standing, Global Labour Flexibility: Seeking Distributive Justice, London: MacMillan Press Ltd, 1999, hlm. 49.

2 The Organisation for Economic Co-operation and Development (OECD), "More flexibility in labour market policy management would boost growth, says OECD," http://www.oecd.org/general/moreflexibilityinlabourmarket policymanagementwouldboostgrowthsaysoecd.htm, diunduh 27 Maret 2017.

3 Menurut Standing, era statutory regulation merupakan era di mana peraturan perundang-undangan memiliki posisi kuat dalam menentukan strategi ekonomi dan sosial suatu negara, termasuk dalam hal regulasi perburuhan. Norma-norma yang paling ideal terkait perburuhan dapat bertahan karena kedigdayaan produksi massal dan stabilitas pekerja. Oleh karenanya, negara yang identik dengan statutory regulation adalah negaranegara kapitalis kesejahteraan dan, pesaing utamanya, negara-negara sosialis. Statutory regulation ini berkebalikan dengan market regulation, di mana stabilitas peraturan perundang-undangan dapat dikatakan lemah karena segala norma ditentukan oleh pasar.

4 Guy Standing, Op.cit., hlm. 59. 
Menurut Standing, pada dasarnya, kebijakan fleksibilitas selalu mengkondisikan ketiadaan jaminan ketenagakerjaan (employment insecurity), mulai dari ketiadaan jaminan kerja, jaminan reproduksi keterampilan, jaminan pendapatan, jaminan pelayanan sosial, hingga jaminan representasi (melalui serikat buruh atau partai buruh misalnya). ${ }^{5}$ Artinya, fleksibilitas tidak melulu berkaitan dengan pemangkasan hak-hak ekonomi buruh, tetapi juga dengan penghancuran hak-hak politik buruh, yang secara tidak langsung (namun efektif) dapat menciptakan employment insecurity.

Di Indonesia, istilah 'fleksibilitas tenaga kerja' baru populer setelah diberlakukannya Undang-Undang Nomor 13 Tahun 2003 tentang Ketenagakerjaan (UU Ketenagakerjaan), di mana fleksibilitas identik dengan strategi informalisasi buruh, outsourcing, sub-kontrak, hubungan kerja yang tidak memiliki standar berdasarkan hukum, dan mobilisasi industri rumahan. Walaupun begitu, migrasi tenaga kerja ke luar negeri, gelombang feminisasi ${ }^{6}$ buruh di era 1970-an hingga akhir 1990-an, dan absennya jaminan kebebasan berserikat pada rezim Soeharto sesungguhnya merupakan bagian dari praktik-praktik fleksibilitas pasar tenaga kerja. Jadi, apabila mengacu pada konsep fleksibilitas, menyebut Orde Baru sebagai representasi statutory regulation dapat dikatakan kurang relevan karena penghancuran serikat buruh, yang berujung pada employment insecurity, tidak dapat dilepaskan dari dimulainya fase ekspansi kapital di Indonesia.

Di negara-negara barat, model flexicurity (flexibility dengan security) diterapkan khususnya pada sektor-sektor yang sarat dengan pekerja perempuan. ${ }^{7}$ Bagi indikator keseteraan gender, fleksibilitas pasar tenaga kerja setidaknya mampu meningkatkan angka partisipasi kerja perempuan secara pesat. Sebagai contoh, di Inggris, fleksibilitas lokasi kerja merupakan jalan pintas yang diambil oleh pemerintah Inggris untuk menurunkan angka pengangguran sekaligus untuk mencitrakan diri sebagai contoh keberhasilan kesetaraan gender dalam mengakses

5 Guy Standing, Op.cit, hlm. 167, 184, 186, 190, 194-197, 213.

6 Feminisasi diambil dari kata feminization. Feminisasi merupakan istilah umum dalam studi feminis (sosiologi feminis, hukum feminis, dan lain sebagainya) yang mengacu pada pergantian peran laki-laki (umumnya dalam hal sektor-sektor ekonomi) oleh peran perempuan. Dalam konteks perburuhan sendiri, istilah feminisasi menjadi populer setelah terbitnya buku Teri L. Caraway yang berjudul Assembling Women: the Feminization of Global Manufacturing pada tahun 2007.

7 - Flexicurity merupakan ide kelompok-kelompok sosial demokratik di negara-negara Uni Eropa untuk menciptakan sistem penyeimbang terhadap kebijakan pasar tunggal di Uni Eropa. Walaupun diterapkan secara beragam di masing-masing negara, ada beberapa prinsip umum dari flexicurity (lihat European Commission, "Flexicurity", http://ec.europa.eu/social/main.jsp?catld=102, diunduh 31 Maret 2017). Pertama, adanya pengaturan kontrak yang fleksibel. Praktik ini dikenal dengan istilah 'easy hire, easy fire'. Kedua, adanya strategi pembelajaran jangka panjang yang komprehensif. Dengan fleksibilitas untuk memiliki pengalaman kerja di berbagai perusahaan, pekerja diharapkan jauh memiliki pengalaman yang matang. Ketiga, adanya kebijakan pasar tenaga kerja yang aktif dan efektif. Keempat, adanya sistem jaminan sosial (social security) modern yang menjadi penyeimbang bagi kebijakan fleksibilitas. 
ekonomi melalui kerja. ${ }^{8}$ Dalam kasus Indonesia, pengiriman tenaga kerja wanita ke berbagai negara tujuan, feminisasi sektor manufaktur di era Orde Baru, informalisasi sektor manufaktur pasca krisis keuangan Asia 1997, dan pemberdayaan ekonomi perempuan melalui home-based industry, yang menjadi tren pemberdayaan perempuan hingga saat ini, dapat dikatakan mampu meningkatkan partisipasi kerja perempuan Indonesia. Namun hal tersebut belum menunjukkan bahwa kesetaraan gender sudah tercapai.

Berdasarkan situasi di atas, Penulis bertujuan untuk memaparkan dampak sesungguhnya aturan fleksibilitas pasar tenaga kerja di Indonesia dan preferensinya pada perempuan terhadap konstruksi gender: apakah peningkatan partisipasi perempuan dalam kerja upahan merupakan bentuk kesetaraan gender? Untuk itu, studi yang menjadi dasar artikel ini menggunakan pendekatan hukum feminis untuk membaca ulang makna dari angka partisipasi kerja perempuan.

\section{B. Pendekatan Hukum Feminis dalam Isu Perburuhan}

1. Pendekatan Hukum Feminis

Pemikiran-pemikiran hukum feminis sesungguhnya tidak dapat dilepaskan dari pemikiran-pemikiran feminis yang berkembang. Akan tetapi, bersentuhan dengan fenomena-fenomena hukum, baik melalui penelitian maupun melalui praktik hukum, membuat pemikir hukum feminis justru mempertanyakan keyakinan para pemikir feminis yang mengusung masing-masing pemikirannya (liberal, radikal, Marxist, dan lain sebagainya). Pendekatan hukum feminis sangat penting dalam pembahasan topik perburuhan umumnya dan topik fleksibilitas khususnya, yakni untuk memahami bahwa angka partisipasi perempuan tidak selalu menjadi indikator kesetaraan dan keadilan gender.

\section{a. Belum tercapainya "netral-gender"}

Standar yang ada dalam nilai-nilai rule of law masih dalam ranah kesetaraan yang sifatnya formal. Bahkan feminis radikal mengkritisi feminis liberal yang cenderung terjebak pada formalitas kesetaraan dalam hukum. Feminis liberal cenderung mendorong perempuan untuk cukup terlihat seperti laki-laki dengan segala standar yang dibuat dan diterapkan kepada laki-laki. Feminis liberal membayangkan bahwa, dengan begitu, perempuan dapat diperlakukan sama dengan laki-laki. ${ }^{9}$ Padahal dalam standar yang dibuat dan diterapkan oleh laki-laki, perempuan tidak mungkin memunculkan perdebatan terhadap nilai-nilai keperempuanan.

\footnotetext{
8 Sandra Fredman, "Women at Work: the Broken Promise of Flexicurity," the Industrial Law Journal, Vol. 33, No. 4, 2004, hlm. 300.

9 Nicola Lacey, "Feminist Legal Theories and the Rights of Women," dalam buku Gender and Human Rights, yang disusun oleh Karen Knop (eds), Oxford: Oxford University Press, 2004, hlm. 20.
} 
Aturan-aturan yang mengakomodasi tindakan-tindakan afirmasi, termasuk yang berbasis kuota, bagi perempuan untuk berpartisipasi di ranah publik justru seringkali membuat upaya untuk mencapai netral-gender semakin jauh. Dalam bidang ketenagakerjaan, gerakan emansipasi perempuan untuk kerja-kerja publik dikritik oleh feminis Marxis karena perempuan justru terjebak dalam sektor-sektor yang memakai penilaian kultur terhadap perempuan sebagai 'jinak, penyayang, penurut, dan sabar' untuk membayar perempuan dengan upah murah. ${ }^{10}$

\section{b. Women-Centred-ness}

Women-centred-ness menempatkan pengalaman dan kepentingan perempuan sebagai pusat perhatian dalam kajian-kajian dan praktik-praktik hukum. Akan tetapi, sulit sekali mencapai sebuah kesepakatan di antara kalangan feminis sendiri tentang perempuan yang mana yang menjadi fokus dalam women-centred-ness ini. ${ }^{11}$ Para feminis liberal kerap mendapatkan pertanyaan terkait ketidakhadiran beberapa kategori perempuan sebagai subjek, sekalipun ada segelintir kategori perempuan yang hadir dalam pembuatan hukum. ${ }^{12}$ Artinya dapat dikatakan bahwa masing-masing kategori perempuan memiliki pengalaman dan konsekuensinya, kepentingan yang berbeda.

Ketika perempuan memenangkan pertarungan untuk diakui setara dengan lakilaki dalam hal membuat kebijakan dan mengontrol kebijakan, mereka seringkali bertindak atas nama semua perempuan. Padahal pengalaman dan kepentingan para perempuan yang diatasnamakan oleh perempuan pemenang tersebut sama sekali tidak muncul dalam kebijakan yang dibuatnya. Dalam hal ini, women-centredness sama opresifnya dengan dominasi laki-laki. Perbedaan kelas sosial, ras, dan seksualitas dapat menjadi faktor-faktor yang menyebabkan munculnya kategorikategori perempuan dengan pengalaman dan kepentingan yang berbeda. ${ }^{13}$

Penyebab utama dari kegagalan strategi women-centred-ness adalah perempuan hanya akan mengatasnamakan konstituen politiknya, bukan para perempuan itu sendiri sebagai kelompok politik. Dengan kata lain, ada kegagalan menemukan sebuah identitas perempuan yang dapat merepresentasikan pengalaman dan kepentingan perempuan, tanpa membedakan latar belakang berdasarkan kelas sosial, ras, dan lain sebagainya. ${ }^{14}$

\footnotetext{
10 lbid.

11 Joanne Conaghan, "Reasessing the Feminist Theoritical Project in Law," Journal of Law and Society, Vol. 27, No. 3, 2000, hlm. 365.

12 Alessandra Tanesini, An Introduction to Feminist Epistemologies, Oxford: Blackwell, 1999, hlm. 6; Judith Butler, Gender Trouble: Feminism and the Subversion of Identity, 1st edition, London: Routledge, 2006, hIm. 33.

13 Elizabeth V Spelman, Inessential Women: Problems of Exclusion in Feminist Thought, Boston: Beacon Press, 1988, hlm. 350.

14 Nancy C. M. Hartstock, Money, Sex, Power: toward a Feminist Historical Materialism, New York: Longman, 1983, hIm. 310 .
} 


\section{c. Pembedaan antara Publik dan Privat}

Kritik ini khususnya ditujukan kepada pemikir feminis liberal yang berasumsi bahwa dunia ini dibagi menjadi 2 (dua) ranah, yakni publik dan privat. Tindakan dan campur tangan negara hanyalah untuk urusan-urusan yang bersifat publik. Sedangkan urusan-urusan yang bersifat privat atau domestik diasumsikan sebagai otonomi individu. Sebagian besar feminis liberal memandang rumah dan keluarga sebagai ranah privat.

Para feminist legal scholars pada dasarnya mempertanyakan asumsi tersebut melalui contoh-contoh kasus kekerasan dalam rumah tangga. ${ }^{15}$ Lebih jauh lagi, dalam konteks perburuhan, unpaid care work, fleksibilitas, dan home-based industry menjadi dasar untuk menguji apakah privat selalu menjadi otonomi individu. Sebagai contoh, kebijakan mengalihkan pelaksanaan pekerjaan, baik secara sebagian atau seluruhnya, berdampak pada terbatasnya hak perempuan untuk menikmati tidak hanya upah lembur, tetapi juga hak reproduksinya.

\section{d. Eksploitasi Ganda}

Di tengah pandangan pemikir feminis Marxist bahwa opresi terhadap perempuan adalah semata-mata persoalan kelas, legal scholars banyak yang mempertanyakan mengapa eksploitasi terhadap perempuan tidak melulu dilakukan oleh laki-laki borjuis. Laki-laki proletar pun menikmati eksploitasi terhadap perempuan. Walaupun begitu, kemudian muncul pandangan baru di kalangan feminis Marxis. Pandangan ini disebut sebagai teori dual system, di mana produksi kapitalis melibatkan eksploitasi produksi terhadap kelas pekerja dan eksploitasi reproduksi terhadap perempuan. Kemampuan kerja reproduktif dari perempuan yang dieksploitasi oleh laki-laki sama saja dengan kemampuan kerja produktif dari kelas pekerja yang dieksploitasi oleh kapitalis. ${ }^{16}$

Yang menjadi masalah ketika diterapkan dalam hukum adalah tidak diakomodasinya eksploitasi terhadap kemampuan kerja reproduktif sebagai sebuah bentuk pelanggaran hukum. Sedangkan berbagai bentuk eksploitasi terhadap kemampuan kerja produktif pada umumnya sudah diakomodasi sebagai sebuah bentuk pelanggaran hak oleh hukum. ${ }^{17}$ Sebagai contoh, pelanggaran 8 (delapan) jam kerja lazimnya sudah diatur oleh hukum sebagai sebuah pelanggaran hak buruh. Akan tetapi mengkondisikan seorang perempuan untuk menanggung jam kerja rumah tangga (mengasuh anak, mencuci, memasak, dan lain sebagainya) lebih tinggi dari laki-laki justru cenderung dibenarkan oleh hukum. Hukum bahkan seringkali mengaturnya sebagai 'kewajiban istri'.

\footnotetext{
15 Nicola Lacey, Loc.cit.

16 Michelle Barrret, Women's Oppression Today: the Marxist/Feminist Encounter, 2nd Edition, London: Verso, 1991.

17 Nicola Lacey, Op.cit., hlm. 23.
} 


\section{Pendekatan Hukum Feminis terhadap Buruh Perempuan}

Dalam literatur hukum perburuhan feminis, ada 2 (dua) hal yang menjadi fokus pembahasan. Pertama adalah memperluas domain hukum perburuhan dengan memasukkan isu imigrasi dan unpaid work atau kerja tak berbayar. Lebih jauh lagi, pemikir hukum perburuhan feminis menekankan pada kerja-kerja pengasuhan, baik yang berbayar maupun yang tak berbayar. Kedua, pemikir hukum perburuhan feminis mendapatkan tantangan dari de-teritorialisasi, di mana subjek dari hukum perburuhan menuntut hukum perburuhan untuk dapat diterapkan secara lintas batas dan lintas bangsa. Konsep hukum positif bagi sebuah negara dan bangsa menjadi sangat dangkal untuk diterapkan dalam konteks hukum perburuhan feminis. ${ }^{18}$

\section{a. Memperluas Konsep'Kerja'}

Posisi rentan perempuan dalam pasar tenaga kerja berkaitan erat dengan pembagian kerja berbasis gender atau the gendered division of labor di dalam keluarga. Pembagian kerja berbasis gender dalam keluarga menjadi awal mula dikotomi makna kerja, dimana salah satunya diabaikan dalam hukum perburuhan. Ada beberapa contoh dikotomi, seperti kerja publik/domestik, produktif/ reproduktif, berbayar/tak berbayar, formal/informal, dan lain sebagainya. ${ }^{19}$ Kerjakerja tak berbayar, reproduktif, domestik, dan informal cenderung tidak mendapatkan tempat dalam hukum perburuhan karena hukum perburuhan yang masih tradisional cenderung memandang kerja sebagai aktivitas untuk mendapatkan imbalan, yakni upah, dan aktivitas untuk orang lain, yang memberikan perintah kerja dan upah.

Kritisi dari pemikir hukum feminis di atas, sayangnya, belum diadopsi oleh pemikir hukum perburuhan. Konsep reproduksi sosial, yang utamanya didapat dari literatur ekonomi politik, belum mendapatkan perhatian dari ahli hukum perburuhan. Reproduksi sosial sendiri adalah sebuah proses sosial yang menjadikan reproduksi, yakni melahirkan anak dan merawat anak, sebagai aktivitas melahirkan (calon) generasi tenaga kerja dan aktivitas menjaga generasi tenaga kerja secara kualitas dan kuantitas. Singkatnya, melahirkan dan merawat anak memiliki fungsi sosial ekonomi. Sementara keluarga menjalankan peran reproduksi sosial, negara membangun supporting system berupa kebijakan-kebijakan pelayanan kesehatan, pendidikan, dan migrasi. ${ }^{20}$ Pelayanan kesehatan untuk mempersiapkan tenaga

18 Judy Fudge, “Commodifying Care Work: Globalization, Gender, and Labour Law," Paper presented at the Inaugural Labour Law Research Network Conference, Barcelona, June 13-15, 2013.

19 Joanne Conaghan dan Kerry Rittich (eds), Labour Law, Work, and Family: Critical and Comparative Perspectives, Oxford: Oxford University Press, 2005, hlm. 38; Kerry Rittich, "Feminization and Contingency: Regulating the Stakes of Work for Women," dalam buku Labour Law in an Era of Globalization: Transformative Practices and Possibilities, yang disusun oleh J. Conaghan, R.M. Fischl, dan K. Klare (eds), Oxford: Oxford University Press, 2002, hlm. 129.

20 Judy Fudge, "Precarious Migrant Status and Precarious Employment: The Paradox of International Rights for Migrant Workers," Comparative Labor Law and Policy Journal, Vol. 34, No. 1, 2012: 95-132, hlm. 100 -101. 
kerja siap pakai yang sehat secara fisik. Pelayanan pendidikan ditujukan untuk menyesuaikan kebutuhan pasar tenaga kerja. Dan migrasi ditujukan untuk mendukung kebutuhan cadangan tenaga kerja di sektor-sektor yang dibutuhkan di negara-negara lain.

Hukum perburuhan tradisional juga telah mengabaikan persoalan unpaid domestic work atau kerja rumah tangga tak berbayar, yang pada umumnya dilakukan oleh perempuan atau istri. Hukum perburuhan tradisional hanya mengakomodasi kerja-kerja yang dianggap produktif, yakni menghasilkan barang dan jasa yang marketable atau sesuai kebutuhan pasar. Sedangkan, kerja-kerja rumah tanggap dianggap bersifat reproduktif karena memiliki lingkup rumah tangga, yang sebagian besar selalu berurusan dengan aktivitas-aktivitas melahirkan dan merawat anak. Sehingga mengintegrasikan kerja-kerja domestik ke dalam hukum perburuhan bukanlah hal yang mudah diterima oleh kebanyakan pemikir hukum perburuhan yang masih tradisional. ${ }^{21}$ Namun yang terjadi adalah muncul berbagai kebijakan perburuhan yang sering disebut sebagai family-friendly policies atau kebijakan ramah keluarga, di mana peran domestik perempuan justru semakin dipertahankan dalam skema-skema kerja tak berbayar.

Daripada melegitimasi kerja rumah tangga sebagai salah bentuk kerja yang nyata sebagaimana kerja produktif, pemerintah lebih memilih untuk menerapkan model-model kerja fleksibel, khususnya fleksibel secara 'tempat' dan 'waktu'. Secara 'tempat', perempuan diharapkan dapat melakukan pekerjaan produktif di rumah, dengan harapan bahwa perempuan tetap dapat melakukan tugas reproduktifnya. Sedangkan fleksibilitas secara waktu membuat kita tidak bisa membedakan alokasi waktu perempuan untuk melakukan kerja produktif dan alokasi waktu perempuan untuk melakukan kerja reproduktif. ${ }^{22}$ Dapat dikatakan bahwa hal ini menjadi pilihan negara dalam pengasuhan anak dibandingkan menyediakan infrastruktur pengasuhan di tempat kerja publik.

\section{b. De-teritorialisasi}

Lain halnya jika membahas kerja-kerja pengasuhan dalam konteks global, di mana kerja pengasuhan sudah dikomodifikasi sebagai salah satu sektor kerja. Kebijakankebijakan perdagangan global pun melegitimasi kerja pengasuhan sebagai salah satu komoditas. Namun dengan adanya pengakuan terhadap kerja pengasuhan sebagai sebuah sektor kerja, apakah hal tersebut memperlemah atau memperkuat pembagian kerja berdasarkan jenis kelamin. Dilema tersebut muncul karena di negara-negara tujuan, pekerja migran perempuan sangat dibatasi pada pekerjaanpekerjaan yang, lagi-lagi, menggunakan nilai-nilai sosial terhadap keperempuanan, seperti pekerja rumah tangga, pengasuh, dan pekerja seks, yang identik dengan

21 Kerry Rittich, Loc.cit.

22 Sandra Fredman, Op.cit., hlm. 302. 
kondisi yang tidak stabil, khususnya terkait dengan upah yang rendah dan tidak adanya jaminan sosial. ${ }^{23}$

Sebelumnya sudah disebutkan bahwa sudah ada kebijakan perdagangan global yang melegitimasi kerja pengasuhan sebagai salah satu komoditas perdagangan. General Agreement on Trade and Services (GATS) di bawah World Trade Organization (WTO) memfasilitasi pengasuhan sebagai komoditi jasa sehingga dapat diperdagangkan dalam skema perdagangan global. ${ }^{24}$ Hukum perburuhan seharusnya dapat menjadi penyeimbang berlakunya GATS di level nasional. Akan tetapi, hukum perburuhan memiliki beberapa keterbatasan. Pertama, hukum perburuhan memiliki keterbatasan teritori, di mana ada kesenjangan aturan yang mengabaikan standar hubungan kerja maupun perlindungan bagi buruh yang bermigrasi ke negara lain. ${ }^{25}$

Keterbatasan konsep hukum perburuhan yang kedua adalah sekalipun kerjakerja pengasuhan telah dilaksanakan dalam skema komoditas jasa, hubungan kerja dalam kerja-kerja pengasuhan sangatlah personal, tanpa pembatasan waktu kerja, dan dilaksanakan di tempat kerja yang privat, yakni rumah tangga. Hukum perburuhan belum mampu menanggulangi kondisi-kondisi tersebut. Sebaliknya hukum perburuhan seringkali menganggap kondisi-kondisi tersebut dapat dimaklumi karena skema kerja yang sangat personal tadi. ${ }^{26}$

\section{c. Menuju Hukum Netral-Gender}

Para ahli hukum perburuhan feminis tidak lagi melihat hukum sebagai alat yang netral, yang mampu memecahkan segala persoalan ketidaksetaraan gender. Hukum juga tidak dipandang sebagai alat yang otonom dari masyarakat. Walaupun begitu, para ahli hukum perburuhan feminis tetap percaya bahwa hukum memiliki dimensi pelembagaan sekaligus normatif. Hukum tetap penting sebagai alat untuk menghasilkan wacana yang berperan penting dalam membentuk cara pandang masyarakat. Dalam hal ini, hukum merupakan alat yang menghasilkan wacana tentang subjek hukum 'laki-laki' dan 'perempuan', yang kemudian membentuk penilaian masyarakat terhadap dimensi 'laki-laki' dan 'perempuan'. Di sini, hukum menjadi bagian dari proses dalam membentuk cara pandang masyarakat terhadap peran laki-laki dan perempuan: apakah setara gender atau bias gender. ${ }^{27}$

Para ahli hukum perburuhan feminis juga memperluas kajian di luar standar hukum yang berlaku secara nasional, yakni norma-norma yang berlaku baik secara regional maupun internasional. Dalam konteks globalisasi, hukum nasional dapat

23 Judy Fudge, "Commodifying Care Work....", Loc.cit.

24 Jane Kelsey, Serving Whose Interests?: the Political Economy of Trade in services Agreements, Oxon: RoutledgeCavendish, 2008, hlm. 189.

25 Judy Fudge, "Precarious Migrant Status and Precarious Employment....", Loc.cit.

26 Ann Stewart, Gender, Law, and Justice in a Global Market, Cambridge: Cambridge University Press, 2011, hlm. 313.

27 Joanne Conaghan, "Reasessing the Feminist Theoritical Project in Law," Op.cit., hlm. 363. 
merupakan hasil interaksi dengan hukum regional maupun hukum internasional. Hukum bukan lagi merupakan system of rules, melainkan merupakan system of discourse. Sehingga banyak ahli hukum perburuhan feminis yang telah memetakan hukum yang berlaku di tingkat lokal, di tingkat nasional, di tingkat regional, hingga di tingkat internasional: bagaimana hukum-hukum tersebut hanya berujung pada sebuah dampak sosial, yang memang diharapkan untuk terbentuk. ${ }^{28}$

\section{Konstruksi Gender dalam Fleksibilitas di Indonesia}

1. Feminisasi dalam Hubungan Industrial Pancasila

Feminisasi adalah preferensi untuk menggunakan perempuan sebagai tenaga kerja. Di era Hubungan Industrial Pancasila, ideologi perburuhan yang diusung oleh pemerintah Orde Baru, gelombang feminisasi yang terjadi antara awal 1970-an hingga akhir 1990-an menjadi strategi untuk mendapatkan posisi sebagai newly industrialized country.

Kebanyakan pemikir perburuhan Indonesia berpendapat bahwa fokus utama dari feminisasi sektor manufaktur di Indonesia adalah di industri-industri padat karya. Pendapat tersebut tidak sepenuhnya salah jika dianalisis dalam konteks negara-negara yang memiliki serikat-serikat buruh dengan posisi tawar tinggi. Pada umumnya, industri-industri padat modal sangat didominasi oleh pekerja laki-laki dengan upah tinggi dan posisi tawar serikat buruh yang kuat. Sehingga buruh perempuan dengan upah rendah tidak dimungkinkan untuk memasuki industri ini. Akan tetapi dalam konteks Indonesia, transisi industri pada modal dari dominasi pekerja laki-laki (dengan upah tinggi) ke dominasi pekerja perempuan (dengan upah rendah) sangat dimungkinkan karena Indonesia, pada saat itu, berada dalam rezim yang sangat represif terhadap serikat buruh. ${ }^{29}$

Terlebih, saat itu mesin-mesin berat pada industri padat modal mulai diganti dengan mesin-mesin berteknologi tinggi, yang dapat dikendalikan oleh perempuan. Akan tetapi, hal ini tetap menggunakan dimensi keperempuanan, seperti teliti, sabar, pencari nafkah tambahan, dan keibuan, dalam mengendalikan teknologi tersebut. Konsekuensi pengggunaan dimensi keperempuanan pada industri padat karya maupun industri padat modal adalah pembenaran diberlakukannya upah rendah.

Transisi ke arah dominasi pekerja perempuan terjadi di industri padat modal maupun di industri padat karya. Apabila dilihat dari Statistik Industri Besar dan

\footnotetext{
28 Ann Stewart, Op.cit., hlm. 61-63.

29 Teri L. Caraway, Assembling Women: The Feminization of Global Manufacturing, 1st edition, New York: Cornell University Press, 2007, hlm. 32. Pada era kekuasaan Soeharto, hanya ada 1 (satu) serikat buruh yang diakui oleh pemerintah, yakni Serikat Pekerja Seluruh Indonesia (SPSI). Ini dikenal sebagai serikat pekerja tunggal. SPSI pun sangat dikooptasi oleh kepentingan rezim penguasa pada saat itu. Adanya SPSI di tingkat perusahaan tidak berarti bahwa ada posisi tawar yang kuat bagi buruh di hadapan pengusaha maupun negara.
} 
Industri Sedang yang dibuat oleh Badan Pusat Statistik (BPS) pada tahun 1994, pada industri padat modal, feminisasi terjadi di sektor elektronik dan sektor tembakau. Sedangkan pada industri padat karya, yang tentunya dengan tingkat upah rendah, feminisasi terjadi terutama pada sektor-sektor alas kaki, garmen, dan manufaktur lainnya. ${ }^{30}$

Feminisasi merupakan salah satu bentuk fleksibilitas karena berbagai insecurity yang menjadi dampaknya. Melegitimasi sexual division of labor di dalam keluarga menjadi 'kepala keluarga' dan 'ibu rumah tangga' berkonsekuensi terhadap perbedaan upah antara laki-laki dan perempuan. Inilah yang menjadi napas dari Undang-Undang Nomor 1 Tahun 1974 tentang Perkawinan (UU Perkawinan) dan Kompilasi Hukum Islam (KHI). Kepala keluarga dipandang sebagai pemimpin dalam keluarga, yang artinya memimpin secara keuangan sebagai pencari nafkah atau breadwinner. Sedangkan, ibu rumah tangga sebagai penanggung jawab segala urusan rumah tangga, seperti pengasuhan anak dan kerja-kerja domestik lainnya. Dengan status 'ibu rumah tangga', perempuan dianggap tidak berkewajiban untuk menafkahi keluarga sebagaimana laki-laki. Dengan begitu, perempuan seringkali identik sebagai 'pencari nafkah tambahan', yang melegitimasi perempuan untuk menerima upah secara fleksibel sekalipun sudah berkeluarga. ${ }^{31}$

Selain UU Perkawinan dan KHI, ada beberapa kebijakan lain yang mendukung feminisasi di Indonesia, seperti Keluarga Berencana (KB). Kebijakan KB, beserta subsidi yang secara besar-besaran diberikan oleh pemerintah Orde Baru, seakanakan diberlakukan untuk memungkinkan emansipasi perempuan dalam kerja publik dan untuk memungkinkan mobilisasi perempuan (untuk bekerja). Hal tersebut memang benar. Akan tetapi celah-celah pekerjaan yang tersedia untuk perempuan, sebagaimana telah dipaparkan tadi, adalah pekerjaan-pekerjaan yang sarat dengan label budaya terhadap dimensi keperempuanan demi politik upah murah.

Selain untuk menciptakan income insecurity, feminisasi dapat mendukung employment insecurity. Lemahnya aturan tentang hak reproduksi perempuan pada era Hubungan Industrial Pancasia membuat perempuan, khususnya dalam hal bersalin dan merawat anak, tidak akan bekerja dalam jangka waktu yang lama. Para pemodal (asing) memahami betul hal tersebut dan menjadikannya sebagai strategi untuk menerapkan employment insecurity tanpa melalui pemutusan hubungan kerja (PHK).

\section{Informalisasi Sektor Manufaktur}

Apabila feminisasi di era Soeharto memiliki skema yang sangat formal, tidak demikian halnya yang terjadi pasca krisis keuangan Asia 1997, sebuah momentum yang juga mengakhiri rezim formalisasi. 
Sebelum 1997, untuk mencapai status newly industrialized country, Indonesia sangat bergantung pada investasi asing dalam industrialisasi. Investasi asing pun dilakukan secara spekulatif dalam jumlah besar. Begitu juga dengan sistem produksi, yakni secara spekulatif, sehingga banyak sekali pabrik-pabrik besar yang berdiri di Indonesia. Setiap pabrik tetap menggunakan merek dagang sesungguhnya (misalnya NIKE) karena memang perusahaan induk yang bersangkutanlah yang menanamkan dan mengelola modalnya. Perusahaan induk hanya memakai Indonesia sebagai lokasi. Perusahaan-perusahaan besar dengan skema inilah yang banyak mempekerjakan buruh perempuan pada era Orde Baru.

Pada saat krisis 1997, kenaikan harga kebutuhan pokok menjadi alasan bagi perusahaan untuk merespon dengan kenaikan upah, yang berarti juga kenaikan ongkos produksi. Sementara itu, Pemerintah Indonesia lebih memprioritaskan dana cadangan yang ada, termasuk bantuan dari International Monetary Fund (IMF), untuk menyelamatkan nilai tukar rupiah daripada untuk mem-bailout perusahaanperusahaan, khususnya perusahaan-perusahaan manufaktur. Hal ini dianggap respon yang terlalu lama bagi pemilik perusahaan-perusahaan manufaktur. Secara eksternal, di negara-negara tujuan ekspor, preferensi masyarakat terhadap produk pun mengalami perubahan, baik dari segi kualitas produk maupun harga produk. ${ }^{32}$ Pada akhirnya, perusahaan-perusahaan manufaktur memilih untuk mengakhiri produksi di Indonesia dan mencari strategi produksi lain atau, bahkan, mencari negara-negara lain yang lebih ramah terhadap investor. Fase de-industrialisasi ini kemudian berujung pada PHK massal. Di sini, sektor-sektor manufaktur yang sebagian besar mempekerjakan buruh perempuan, seperti garmen, merupakan sektor-sektor yang paling terpukul oleh dampak krisis.

Pada masa pemulihan krisis, strategi manufaktur pun diubah secara besarbesaran. Produksi yang tadinya bersifat spekulatif tanpa mempertimbangkan daya beli pasar (baik dalam negeri maupun luar negeri) berubah menjadi produksi yang bersifat just in time (JIT) atau by order. Jadi, produksi hanya dilakukan jika ada pesanan dari perusahaan induk. Perusahaan-perusahaan induk pun tidak lagi berani melakukan produksi secara langsung di Indonesia, melainkan melalui kemitraan dengan pengusaha-pengusaha Indonesia. ${ }^{33}$

32 Maria Mies dalam Patriarchy and Accumulation on a World Scale menyebutkan bahwa dalam sejarah dunia, krisis tidak pernah terjadi tanpa adanya penumpukan komoditas. Sistem produksi yang spekulatif, dibarengi dengan turunnya daya beli konsumen, hampir selalu menjadi penyebab terjadinya penumpukan komoditas tersebut. Lihat Maria Mies, Patriarchy and Accumulation on a World Scale, 1st edition, New Jersey: Zed Books, 1986.

33 Pengusaha-pengusaha Indonesia yang dipilih menjadi mitra perusahaan induk mendirikan perusahaan tidak dengan nama sesuai merek yang dimiliki perusahaan induk. Sebagai contoh, proses produksi produk NIKE tidak lagi dilakukan oleh sebuah perusahaan bernama NIKE, melainkan oleh, salah satunya, PT. Pou Yuen di Cianjur. Meskipun begitu, karena by order system, PT. Pou Yuen berhak melakukan produksi untuk produk selain NIKE jika target produksi untuk NIKE sudah selesai. 


\section{a. Informalisasi Manufaktur sebagai Bentuk Fleksibilitas}

Just in time atau JIT menjadi pemicu utama terjadinya informalisasi. JIT adalah cara produksi yang memaksimalkan pasokan input pada titik waktu yang tepat. ${ }^{34}$ Teknik ini menjadi sangat efisien di mata para pemodal karena industri manufaktur tidak perlu menyediakan stok input, seperti modal, bahan baku, dan buruh, hanya untuk menunggu datangnya order dari perusahaan buyer. Hubungan antara perusahaan induk dan perusahaan yang melakukan produksi adalah hubungan sub-kontrak. Melalui hubungan sub-kontrak tersebut, perusahaan induk melakukan perjanjian dengan perusahaan mitra hanya dalam lingkup produksi, target produksi, dan biaya keseluruhan. ${ }^{35}$ Sehingga buruh-buruh yang direkrut oleh perusahaan mitra menjadi tanggung jawab dari perusahaan mitra sendiri karena hubungan kerja pun memang hanya terjadi di antara buruh-buruh dan perusahaan mitra. Konsekuensinya buruh tidak dapat meminta pertanggungjawaban dari perusahaan induk.

Sistem JIT sendiri merupakan praktik yang mencakup beberapa bentuk fleksibilitas pasar tenaga kerja, yakni:

1. Kontrak pendek: kontrak dibuat untuk jangka waktu yang pendek, sesuai dengan kebutuhan produksi dalam sistem JIT, dengan perpanjangan yang sangat dapat dinegosiasikan;

2. Manipulasi jam kerja dan manipulasi upah (lembur): sistem JIT seringkali memaksa perusahaan mitra untuk mengerjakan target produksi dalam jangka waktu yang pendek, di mana pembatasan 8 (delapan) jam kerja menjadi tidak efektif untuk sistem JIT dan pembayaran upah lembur tidak efisien. Sehingga perusahaan pada umumnya memberikan pekerjaan rumah untuk buruh di luar jam kerja dengan cara meminjamkan alat produksi, seperti mesin jahit, untuk dibawa pulang oleh buruh. Dalam praktik yang lebih buruk, buruh direkrut sebagai buruh paruh waktu, di mana sebagian besar waktu di rumah digunakan buruh untuk melakukan produksi;

3. Sistem shift: beberapa perusahaan tidak memilih untuk memberikan pekerjaan rumah untuk buruh karena alasan pengawasan kualitas. Sistem shift seringkali menjadi pilihan jika dinilai lebih efisien dibandingkan membayar upah lembur kepada seorang buruh; dan

4. Sub-Kontrak: dalam sistem JIT, buruh direkrut secara borongan melalui perusahaan mitra yang melakukan produksi. Dengan borongan,

34 Wahyu W. Basjir, "Informalisasi dan Tantangan Perburuhan," Jurnal Analisis Sosial, Vol. 8, No. 3, 2003, hlm. 1-20.

35 Undang-Undang Nomor 25 Tahun 2004 tentang Sistem Perencanaan Pembangunan Nasional (SPPN) sudah melegitimasi adanya sektor-sektor ekonomi yang lebih strategis apabila dijalankan dalam skema informal, yakni sektor manufaktur. Bahkan kemudian, Undang-Undang Nomor 17 Tahun 2007 tentang Rencana Pembangunan Jangka Panjang Nasional (RPJPN) beserta turunan melalui Rencana Pembangunan Jangka Menengah Nasional (RPJMN) memberikan detail bidang-bidang usaha yang diarahkan untuk diselenggarakan dalam skema informalisasi. 
kemungkinan-kemungkinan over time dalam produksi tidak dipertimbangkan dalam perjanjian antara perusahaan induk dan perusahaan mitra.

Bentuk-bentuk fleksibilitas yang menjadi dampak informalisasi sektor manufaktur di atas bukanlah tanpa legitimasi dari peraturan perundang-undangan yang ada. Mengenai kotrak jangka pendek, Pasal 59 UU Ketenagakerjaan melegitimasi kontrak dalam jangka pendek.

1. Perjanjian kerja untuk waktu tertentu hanya dapat dibuat untuk pekerjaan tertentu yang menurut jenis dan sifat atau kegiatan pekerjaannya akan selesai dalam waktu tertentu, yaitu:

a. pekerjaan yang sekali selesai atau yang sementara sifatnya;

b. pekerjaan yang diperkirakan penyelesaiannya dalam waktu yang tidak terlalu lama dan paling lama 3 (tiga) tahun;

c. pekerjaan yang bersifat musiman; atau

d. pekerjaan yang berhubungan dengan produk baru, kegiatan baru, atau produk tambahan yang masih dalam percobaan atau penjajakan.

2. Perjanjian kerja untuk waktu tertentu tidak dapat diadakan untuk pekerjaan yang bersifat tetap.

3. Perjanjian kerja untuk waktu tertentu dapat diperpanjang atau diperbaharui.

4. Perjanjian kerja waktu tertentu yang didasarkan atas jangka waktu tertentu dapat diadakan untuk paling lama 2 (dua) tahun dan hanya boleh diperpanjang 1 (satu) kali untuk jangka waktu paling lama 1 (satu) tahun.

5. Pengusaha yang bermaksud memperpanjang perjanjian kerja waktu tertentu tersebut, paling lama 7 (tujuh) hari sebelum perjanjian kerja waktu tertentu berakhir telah memberitahukan maksudnya secara tertulis kepada pekerja/ buruh yang bersangkutan.

6. Pembaruan perjanjian kerja waktu tertentu hanya dapat diadakan setelah melebihi masa tenggang waktu 30 (tiga puluh) hari berakhirnya perjanjian kerja waktu tertentu yang lama, pembaharuan perjanjian kerja waktu tertentu ini hanya boleh dilakukan 1 (satu) kali dan paling lama 2 (dua) tahun.

Pasal di atas dapat dikatakan memberikan celah untuk memberlakukan kontrak dengan jangka waktu yang pendek. Definisi pekerjaan yang bersifat tetap juga terlalu luas, yakni pekerjaan yang terus-menerus, tidak terputus-putus, tidak dibatasi waktu, dan bukan pekerjaan musiman. Sedangkan, sistem JIT atau by order selalu mensyaratkan pembatasan waktu pengerjaan produk dan seringkali dilakukan dengan cara 'sekali selesai'. Dengan demikian, pekerjaan dengan sistem JIT dapat dikategorikan sebagai pekerjaan tidak tetap.

Mengenai jam kerja, Pasal 77 UU Ketenagakerjaan memang mengatur tentang jam kerja. Akan tetapi, dalam ayat-ayatnya, pasal tersebut dapat dikatakan memang memberikan ruang untuk adanya jam kerja yang dapat dinegosiasikan, yakni: 
1. Setiap pengusaha wajib melaksanakan ketentuan waktu kerja.

2. Waktu kerja sebagaimana dimaksud dalam ayat (1) meliputi:

a. 7 (tujuh) jam 1 (satu) hari dan 40 (empat puluh) jam 1 (satu) minggu untuk 6 (enam) hari kerja dalam 1 (satu) minggu; atau

b. 8 (delapan) jan 1 (satu) hari dan 40 (empat puluh) jan 1 (satu) minggu untuk 5 (lima) hari kerja dalam 1 (satu) minggu

3. Ketentuan waktu kerja sebagaimana dimaksud dalam ayat (2) tidak berlaku bagi sektor usaha atau pekerjaan tertentu.

Dapat dikatakan bahwa ayat 3 memberikan ruang untuk pelanggaran waktu kerja bagi sektor usaha atau pekerjaan tertentu, yang sangat longgar batasannya.

\section{b. Dampak Bagi Perempuan}

Dengan bentuk-bentuk fleksibilitas dalam sistem JIT di atas, bagi perempuan sebagai pekerja mayoritas dalam sektor manufaktur, dampaknya lebih daripada kehilangan hak atas upah lembur ataupun kehilangan jaminan akan kelangsungan kerja. Secara konstruksi gender, beberapa dampak informalisasi melalui JIT antara lain sebagai berikut:

1. Hilangnya hak atas kesehatan reproduksi

Dengan kerja borongan untuk mengejar target produksi, selama 3 (tiga) bulan misalnya, buruh perempuan terpaksa melupakan haknya untuk menikmati cuti haid karena dianggap tidak efektif untuk mengejar target produksi. Sekalipun pengusaha menerapkan model 'pekerjaan rumah' dalam mengejar target produksi, buruh perempuan pun belum tentu dapat menikmati haknya atas cuti haid. Lebih dari itu, buruh yang sedang hamil tidak akan menjadi preferensi dari pengusaha, khususnya pada kehamilan trimester ke-3 karena sudah mendekati waktu persalinan.

2. Kembalinya Housewifization (pe-rumahtangga-an perempuan)

Dalam konsep feminis-Marxis, housewifization ini tidak lepas dari kepentingan ekonomi politik. Inilah yang dicerminkan oleh informalisasi sektor manufaktur yang terjadi di Indonesia. Penerapan 'pekerjaan rumah' seringkali dilabeli dengan 'kemitraan' atau 'usaha kecil menengah dan koperasi/UKMK'. Bahkan pemerintah berdalih bahwa home-based job memberi kesempatan bagi perempuan untuk dapat melaksanakan tugas-tugas kerumahtanggaannya di sela-sela proses produksi rumahan. Terlebih beberapa lembaga donor asing sering berargumentasi bahwa ini merupakan bagian dari pemberdayaan perempuan secara ekonomi. Padahal dengan melakukan proses produksi di rumah, justru semakin menegaskan bahwa kerja-kerja kerumahtanggaan merupakan peran tunggal dari perempuan. Hal ini tentunya sangat kontra-produktif dengan gerakan kesetaraan gender, di mana lakilaki seharusnya memiliki peran dalam kerja-kerja kerumahtanggaan.

Secara makro-ekonomi, home-based production bukan sekedar penggunaan dimensi keperempuanan untuk mewujudkan efisiensi ongkos produksi. Lebih dari itu, karena krisis 1997 menyebabkan penumpukan hasil produksi (yang tidak terjual 
di pasar ekspor), home-based production merupakan mobilisasi buruh perempuan untuk turut menjadi agen konsumsi keluarga melalui pembelian barang-barang hasil produksi yang mengendap di dalam negeri. ${ }^{36}$ Mendukung hal tersebut, di Jabotabek (Jakarta, Bogor, Tangerang, dan Bekasi), pemerintah menaikkan upah minimum riil sebesar $24 \%$ pada tahun 2000 dan sebesar 33\% hingga 36\% pada tahun 2001. ${ }^{37}$ Namun pada praktiknya, kenaikan upah ini bukan didasari oleh upaya memperbaiki kesejahteraan buruh, melainkan untuk meningkatkan daya beli buruh, khususnya di sektor manufaktur, yang mayoritas buruhnya adalah perempuan. ${ }^{38}$

\section{Pekerja Rumah Tangga dan Migrasi Global}

Sebagaimana International Labor Organization (ILO) mengutip data Survey Tenaga Kerja Nasional 2012, terdapat 2.555 .000 pekerja rumah tangga (PRT) berusia 15 (lima belas) tahun ke atas yang bekerja di Indonesia, khususnya di Pulau Jawa. ${ }^{39} \mathrm{Di}$ luar negeri, PRT pun mendominasi bidang kerja para tenaga kerja Indonesia, yang mayoritas dilaksanakan oleh tenaga kerja perempuan.

36 Mies (1986) sudah mengingatkan para pemikir feminis untuk menyadari sejarah krisis ekonomi di masa lampau, di mana perempuan selalu menjadi agen penanggulangan melalui mobilisasi perannya sebagai agen konsumsi keluarga. Dan ini akan terus berulang dalam berbagai krisis di masa mendatang.

37 Smeru Institute, Wage and Employment Effects of Minimum Wage Policy in the Indonesian Urban Labor Market, Jakarta: Smeru Institute, 2001.

38 Agus Pratiwi, "The Inequity in Gender Mainstreaming Policy under Denationalized Governance," Paper presented at International Conference of Gender, Neoliberalisme, and Financial Crisis, University of York, UK, 27 September 2013.

39 International Labor Organization (ILO) Jakarta, Technical Report: the Estimation of Total Domestic Workers in Indonesia, Jakarta: ILO, 2013, hlm. 46, 50, 52. Dapat pula diunduh di http://www.ilo.org/wcmsp5/ groups/public/---asia/---ro-bangkok/---ilo-jakarta/documents/publication/wcms 241123.pdf, diakses 30 Maret 2017. 
Tabel 1. Bidang Kerja Tenaga Kerja Indonesia di Luar Negeri

\begin{tabular}{|c|l|c|c|c|c}
\hline NO & \multicolumn{1}{|c|}{ JABATAN } & $\mathbf{2 0 1 2}$ & $\mathbf{2 0 1 3}$ & $\mathbf{2 0 1 4}$ & $\mathbf{2 0 1 5}$ \\
\hline 1 & Dosmetic Worker & 164,981 & 168,318 & 133,390 & 52,328 \\
\hline 2 & Caregiver/Caretaker & 52,565 & 48,188 & 49,069 & 44,941 \\
\hline 3 & Plantation Worker & 36,478 & 47,598 & 47,790 & 38,526 \\
\hline 4 & Operator & 40,347 & 46,799 & 38,836 & 35,187 \\
\hline 5 & DeckHand & 12,283 & 11,249 & 10,410 & 1,166 \\
\hline 6 & General Worker & 8,488 & 13,834 & 8,920 & 5,521 \\
\hline 7 & Housekeepers & 16,006 & 8,301 & 6,272 & 5,956 \\
\hline 8 & Labour & 19,493 & 5,854 & 4,678 & 1,390 \\
\hline 9 & Worker & 19,161 & 13,042 & 10,154 & 13,399 \\
\hline 10 & Production Operator & 7,076 & 10,520 & 9,283 & 3,924 \\
\hline 11 & Driver & 9,141 & 7,832 & 7,450 & 1,250 \\
\hline 12 & Construction Worker & 5,040 & 10,204 & 7,093 & 3,089 \\
\hline 13 & Able Body Seaman & 7,796 & 8,719 & 4,810 & 596 \\
\hline 14 & Fisherman & 5,213 & 5,559 & 4,852 & 1,866 \\
\hline 15 & Construction Labourers & 5,813 & 2,835 & 3,668 & 1,839 \\
\hline 16 & Gardener & 2,580 & 3,831 & 3,214 & 2,245 \\
\hline 17 & Steaward & 5,341 & 2,690 & 1,380 & 257 \\
\hline 18 & Cleaning Service & 1,874 & 2,409 & 4,973 & 2,667 \\
\hline 19 & Waiter & 4,144 & 3,153 & 1,958 & 2,310 \\
\hline 20 & Lainnya & 70,789 & 91,233 & 71,672 & 57,279 \\
\hline & TOTAL & 494,609 & 512,168 & 429,872 & 275,736 \\
\hline
\end{tabular}

Sumber: Badan Nasional Penempatan dan Perlindungan Tenaga Kerja Indonesia (BNP2TKI), 2016.

Tabel 2. Persentase Jumlah Perempuan dan Laki-laki yang Bekerja di LN

\begin{tabular}{|c|c|c|c|c|c|c|}
\hline NO & TAHUN & $\begin{array}{c}\text { JUMLAH TOTAL TKI YG } \\
\text { DILAYANI }\end{array}$ & PEREMPUAN & $\mathbf{\%}$ & LAKL-LAKI & \% \\
\hline 1 & 2011 & 586.802 & 376.686 & 64 & 210.116 & 36 \\
\hline 2 & 2012 & 494.609 & 279.784 & 57 & 214.825 & 43 \\
\hline 3 & 2013 & 512.168 & 276.898 & 54 & 235.170 & 46 \\
\hline 4 & 2014 & 429.872 & 243.629 & 57 & 186.243 & 43 \\
\hline 5 & 2015 & 275,736 & 166.771 & 60 & 108.965 & 40 \\
\hline
\end{tabular}

Sumber: BNP2TKI

Apabila melihat data BNP2TKI tentang bidang kerja TKI di luar negeri, sebenarnya jumlah pekerja Indonesia di bidang 'domestic worker' jauh lebih banyak dari angka yang disebutkan dalam tabel. Hal ini terkait pemahaman BNP2TKI yang belum menyeluruh terhadap pengertian 'pekerja rumah tangga', yang juga mencakup 'caregiver/caretaker' dan 'housekeeper'. 
Menurut ILO, dalam kasus PRT yang bekerja di dalam negeri, PRT tidak memiliki batasan jam kerja, hari libur, upah minimum, dan jaminan kesehatan/ketenagakerjaan. ${ }^{40} \mathrm{Hal}$ ini dapat dipahami karena UU Ketenagakerjaan belum mengakomodasi model hubungan kerja yang dipraktikkan dalam pekerjaan kerumahtanggaan, yang pada umumnya bersifat fleksibel, di mana hubungan kerja mengedepankan kekeluargaan dan negosiasi hak. Konkritnya tidak ada perjanjian kerja formal antara PRT dan majikannya berdasarkan standar UU Ketenagakerjaan.

Dalam hal PRT di luar negeri, migrasi merupakan bentuk fleksibilitas dalam hal lokasi. Sebenarnya, kawasan regional, baik di negara-negara Association of South East Asian Nations (ASEAN) maupun di negara-negara tujuan di kawasan Gulf Cooperation Council (GCC), sudah membatasi free movement of person hanya untuk skilled worker. Akan tetapi GATS mengakomodasi low-skilled reserves sebagai komoditas perdagangan jasa, termasuk sektor kerumahtanggaan. Sehingga ada peraturan di tingkat global yang pada praktiknya belum bisa diimbangi oleh peraturan di tingkat regional maupun di tingkat nasional.

Dari sudut pandang hukum feminis, pekerja migran perempuan sangat dibatasi pada pekerjaan-pekerjaan yang, lagi-lagi, menggunakan nilai-nilai sosial terhadap keperempuanan, seperti pekerja rumah tangga, pengasuh, dan pekerja seks, yang identik dengan kondisi yang tidak stabil, khususnya terkait dengan upah yang rendah dan tidak adanya jaminan sosial. ${ }^{41}$ Situasi tersebut tidak sepenuhnya memposisikan negara-negara tujuan sebagai pihak yang bersalah dalam menggunakan nilai-nilai sosial terhadap keperempuanan (perempuan Indonesia) dan memakainya sebagai alasan untuk menerapkan 'buruh murah'. Faktor internal sangat menentukan situasi tersebut. Menggunakan nilai-nilai sosial terhadap perempuan sebagai makhluk yang sabar, telaten, dan nrimo sudah merupakan kewajaran yang mendarah daging dalam kehidupan bermasyarakat di Indonesia. Dan nilai-nilai sosial tersebut menjadi trade off dari negara-negara asal pekerja perempuan migran untuk mendapatkan tempat dalam perdagangan global.

\section{Penutup}

Feminisasi di era Hubungan Industrial Pancasila, informalisasi di era pos-Soeharto, dan sektor PRT beserta migrasi global terhadapnya merupakan skema-skema fleksibilitas pasar tenaga kerja yang secara kuantitas telah menunjukkan peningkatan partisipasi perempuan dalam sektor-sektor kerja publik. Akan tetapi dari perspektif hukum feminis, skema-skema fleksibilitas tersebut telah menggunakan nilai-nilai sosial terhadap perempuan yang justru kontra-produktif dengan gerakan kesetaraan gender.

\footnotetext{
40 Ibid., hlm. 65-69.

41 Judy Fudge, “Commodifying Care Work....", Loc.cit.
} 
Feminisasi mendapatkan legitimasi dari UU Perkawinan dan KHI melalui pengaturan sexual division of labor untuk menerapkan 'pencari nafkah tambahan' pada buruh perempuan, termasuk pada buruh perempuan yang sudah menikah. Pasca Orde Baru, informalisasi diterapkan pada sektor-sektor yang di-feminisasi di rezim sebelumnya. Lokasi proses produksi dipindahkan dari pabrik ke unit rumah tangga dengan harapan perempuan tetap dapat melaksanakan peran gandanya sebagai pekerja sekaligus ibu rumah tangga (housewifization). Begitu pula dalam skema PRT dan migrasi global yang ditunjukkan dengan perempuan sebagai mayoritas pekerjanya dan kerumahtanggaan sebagai mayoritas bidang kerjanya. Sehingga bagi buruh perempuan, pola penggunaan nilai-nilai sosial terhadap perempuan cenderung sama sekalipun dalam skema fleksibilitas yang berbeda dari waktu ke waktu. Bentuk-bentuk fleksibilitas yang menjadi dampak dari penggunaan nilai-nilai sosial tersebut juga cenderung sama, yakni employment insecurity dan income insecurity.

\section{Daftar Pustaka}

\section{Buku}

Barret, Michelle, Women's Oppression Today: the Marxist/Feminist Encounter, 2nd Edition, Verso, London, 1991.

Butler, Judith, Gender Trouble: Feminism and the Subversion of Identity, 1st edition, Routledge, London, 2006.

Caraway, Teri L, Assembling Women: The Feminization of Global Manufacturing, 1st edition, Cornell University Press, New York, 2007.

Conaghan, J., R.M. Fischl, and K. Klare (eds), Labour Law in an Era of Globalization:

Transformative Practices and Possibilities, Oxford University Press, Oxford, 2002.

Conaghan, Joanne, dan Kerry Rittich (eds), Labour Law, Work, and Family: Critical and Comparative Perspectives, Oxford University Press, Oxford, 2005.

Kelsey, Jane, Serving Whose Interests?: the Political Economy of Trade in services Agreements, Routledge-Cavendish, Oxon, 2008.

Knop, Karen (eds), Gender and Human Rights, Oxford University Press, Oxford, 2004.

Mies, Maria, Patriarchy and Accumulation on a World Scale, 1st Edition, Zed Books, New Jersey, 1986.

Smeru Institute, Wage and Employment Effects of Minimum Wage Policy in the Indonesian Urban Labor Market, Smeru Institute, Jakarta, 2001.

Spelman, Elizabeth V, Inessential Women: Problems of Exclusion in Feminist Thought, Beacon Press, Boston, 1988.

Standing, Guy, Global Labour Flexibility: Seeking Distributive Justice, MacMillan Press Ltd, London, 1999. 
Stewart, Ann, Gender, Law, and Justice in a Global Market, Cambridge University Press, Cambridge, 2011.

Tanesini, Alessandra, An Introduction to Feminist Epistemologies, Blackwell, Oxford, 1999.

\section{Dokumen Lain}

Conaghan, Joanne, "Reasessing the Feminist Theoritical Project in Law," Journal of Law and Society, Vol. 27, No. 3, September 2000.

European Commission, "Flexicurity", http://ec.europa.eu/social/main.jsp?catld=102, diunduh 31 Maret 2017.

Fredman, Sandra, "Women at Work: the Broken Promise of Flexicurity," The Industrial Law Journal, Vol. 33, No. 4, 2004.

Fudge, Judy, "Precarious Migrant Status and Precarious Employment: The Paradox of International Rights for Migrant Workers," Comparative Labor Law and Policy Journal, Vol. 34, No. 1, 2012.

, "Commodifying Care Work: Globalization, Gender, and Labour Law," Paper presented at the Inaugural Labour Law Research Network Conference, Barcelona, June 13-15 2013.

Organization for Economic Co-operation and Development, "More flexibility in labour market policy management would boost growth", available from http://www.oecd.org/general/moreflexibilityinlabourmarketpolicy managementwouldboostgrowthsaysoecd.htm, diunduh 8 Agustus 2016.

\section{Dokumen Hukum}

Undang-Undang Nomor 1 Tahun 1974 tentang Perkawinan.

Undang-Undang Nomor 13 Tahun 2003 tentang Ketenagakerjaan.

Kompilasi Hukum Islam. 